\title{
Methods of improvement chalcedonite processing effectiveness with the use of density separation
}

\section{Introduction - industrial utilization of chalcedonite}

Chalcedonite is a siliceous sedimentary rock, which can be classified as an unique raw material, due to the small area of occurrence. In Poland, the only exploited deposit of chalcedonite ("Teofilów" deposit), is located in the area of the city of Inowłódz. Chalcedonite is a material with a significant potential of applications in road construction, as a filter material for water purification and waste water treatment, in the cement industry, and as a raw material for cristobalite and wollastonite production (Tchórzewska et. al 2001; Sałaciński and Puff 2003; Kosk 2010; Michel 2011; Naziemiec et. al 2017). The uniqueness of this material and a wide range of its potential industrial applications requires that the technological process of chalcedonite enrichment should be carried out in a manner which ensures the optimal utilization of this valuable material.

Some problems in chalcedonite processing occur due to its diversity in terms of petrographic composition, which affects the variability of some physical and mechanical properties of the material (Ratajczak and Wyszomirski 1991; Tchórzewska 1995; Tchórzewska 1997). For example, particles of natural aggregates usually have a volumetric density within the range of 2.5 to $2.7 \mathrm{Mg} / \mathrm{m}^{3}$. Water absorption of such aggregates typically does not exceed

\footnotetext{
* Ph.D. Eng., Institute of Ceramics and Building Materials, Division of Glass and Building Materials in Krakow, z.naziemiec@icimb.pl, sekretariat_krakow@icimb.pl

** Ph.D. Eng., Associate Professor of AGH, AGH University of Science and Technology, Department of Environmental Engineering and Mineral Processing, Krakow; e-mail: dsaramak@agh.edu.pl
} 
$3 \%$ or $4 \%$ and it is often less than $1 \%$. Silica aggregates (eg. chalcedonite) have densities between 2.0 and $2.4 \mathrm{Mg} / \mathrm{m}^{3}$. Such aggregates have a very high porosity and water absorption, which is a disadvantage when the rock is used in concrete production. The particles of material with various porosity and water adsorption are usually mixed in the rock deposit, which prevents its selective mining. Small differences in density, in turn, result in the fact that in technological circuits of chalcedonite processing, density separation operations are not applied. In processes of mineral aggregates production, the density separation is used only for the purification of aggregate particles from light impurities, weakened particles and in recovering raw materials from the tails (Kowol 2015). The application of separation for particles of aggregates with different density and water absorption may be beneficial due to the possibility of optimal utilization of the obtained products. This applies in particular to chalcedonite rock. Therefore, the main goal of the paper is to analyze the possibility of the application of chalcedonite enrichment technology based on its density separation. The obtained results have confirmed the assumptions of authors in this field and may help with the more effective industrial utilization of products obtained from chalcedonite. All the results presented in the paper in tables and figures come from various investigations of the authors, carried out at the Institute of Ceramics and Building Materials and the AGH UST.

Chalcedonite from the "Teofilów" deposit can be characterized by high lithological variability. The porous and creamy-gray minerals occur In the roof parts of the deposit. In the central part of the deposit, more concise chalcedonite minerals, milky and grayish-blue in colour dominate. A variety of cream-gray chalcedonite with various degree of compactness occurs in the floor areas of deposit (Ratajczak and Wyszomirski 1991; Tchórzewska et al. 1997). Chacedonite consists mainly of cryptocrystalline and microcrystalline chalcedony, and contains small amounts of autogenous and detrital quartz. A characteristic feature of all types of chalcedonite are the pores (voids) which are present in various amounts (Kosk 2008). Depending on the origin and the method, the mechanical processing of chalcedonite products may characterized by some variability in chemical composition. An average chemical composition of chalcedonite was presented in Table 1 (Final Report 1997).

Table 1. The average chemical composition of chalcedonite from the "Inowłódz" mine

Tabela 1. Średni skład chemiczny chalcedonitu z kopalni „Inowłódz”

\begin{tabular}{|c|c|c|c|c|c|c|c|c|c|c|}
\hline \multicolumn{10}{|c|}{ Component - percentage content [\%] } \\
\hline $\mathrm{SiO}_{2}$ & $\mathrm{Al}_{2} \mathrm{O}_{3}$ & $\mathrm{Fe}_{2} \mathrm{O}_{3}$ & $\mathrm{CaO}$ & $\mathrm{MgO}$ & $\mathrm{K}_{2} \mathrm{O}$ & $\mathrm{Na}_{2} \mathrm{O}$ & $\mathrm{SO}_{3}$ & $\mathrm{TiO}_{2}$ & $\mathrm{P}_{2} \mathrm{O}_{5}$ & Roasting loss \\
\hline 96 & 1.1 & 0.2 & 0.05 & 0.04 & 0.11 & 0.05 & 0.03 & 0.07 & 0.02 & 1.1 \\
\hline
\end{tabular}

Chalcedonite, as unique raw material, was the subject of much research and implementations. A description of its multiple applications can be found in numerous publications (Ratajczak and Wyszomirski 1991; Raport Końcowy 1997; Tchórzewska i in. 2001; Sałaciński 
and Puff 2003; Garbacik 2005; Kosk 2008, 2010; Michel 2011). This article highlights the particularly significant problems of its processing as well as the most important and new directions for its utilization.

The basic direction of the utilization of chalcedonite from the "Inowłódz" Mine is the production of aggregates and mixtures of aggregates used in road construction. Some properties of the chalcedonite aggregates are presented in Table 2.

Chalcedonite used as an aggregate for concrete allows concrete class C 25/30 to be obtained. The basic qualitative characteristics of the concrete with chalcedonite aggregate are shown in Table 3 (Mróz and Naziemiec 2007).

Table 2. Properties of chalcedonite aggregate from the "Inowłódz" mine

Tabela 2. Właściwości kruszyw chalcedonitowych z kopalni „Inowłódz”

\begin{tabular}{|l|c|c|c|c|c|}
\hline \multirow{2}{*}{$\begin{array}{c}\text { Feature of } \\
\text { aggregate }\end{array}$} & Type of norm & Unit & \multicolumn{3}{c|}{ Type of tested aggregate } \\
\cline { 5 - 6 } & & & grits $2 / 8 \mathrm{~mm}$ & grits 8/16 mm & grits 16/31 mm \\
\hline Dust content & PN-EN 933-1 & $\%$ & 3.3 & 5.8 & 1.8 \\
\hline Flatness index & PN-EN 933-3 & $\%$ & 12 & 9 & 14 \\
\hline Los Angeles index & PN-EN 1097-2 & $\%$ & 35 & 32 & - \\
\hline Deval index & PN-EN 1097-1 & $\%$ & - & 37 & 0.5 \\
\hline Frost resistance & PN-EN 1367-1 & $\%$ & 1.0 & 1.9 & 2.39 \\
\hline Density $\rho_{a}$ & PN-EN 1097-6 & $\mathrm{Mg} / \mathrm{m}^{3}$ & 2.50 & 2.44 & 1.90 \\
\hline Density $\rho_{r d}$ & PN-EN 1097-6 & $\mathrm{Mg} / \mathrm{m}^{3}$ & 1.78 & 1.80 & 2.10 \\
\hline Density $\rho_{s s d}$ & PN-EN 1097-6 & $\mathrm{Mg} / \mathrm{m}^{3}$ & 2.06 & 2.07 & 10.8 \\
\hline Adsorbability & PN-EN 1097-6 & $\%$ & 16.4 & 14.5 & \\
\hline
\end{tabular}

Table 3. Properties of the concrete made on the basis of the chalcedonite aggregate

Tabela 3. Właściwości stwardniałego betonu na bazie kruszywa chalcedonitowego

\begin{tabular}{|c|c|c|c|}
\hline Feature of concrete & Type of norm & Unit & Value \\
\hline Freezing/defrosting resistance after 150 cycles - mass loss & PN-85/B-04500 & $\%$ & 1.0 \\
\hline Freezing/defrosting resistance after 150 cycles - decrease of compression strength & PN-85/B-04500 & $\%$ & 0.0 \\
\hline Density of hardened concrete saturated with water & PN-EN 12390-7 & $\mathrm{Mg} / \mathrm{m}^{3}$ & 2.08 \\
\hline Water absorption & PN-88/B-06250 & $\%$ & 14.0 \\
\hline Compressive strength after 28 days & PN-EN 12390-3 & $\mathrm{MPa}$ & 34.6 \\
\hline Depth of water penetration under pressure $0.5 \mathrm{MPa}$ & PN-EN 12390-8 & $\mathrm{mm}$ & 32 \\
\hline
\end{tabular}


Despite relatively good qualitative parameters of the concrete, chalcedonite aggregate is not commonly used in concrete production due to its high absorbability. This feature increases the water-to-cement $(\mathrm{w} / \mathrm{c})$ ratio in the concrete mix, which is disadvantageous. The $(\mathrm{w} / \mathrm{c})$ ratio in the concrete should not exceed 0.6 . Using a chalcedonite in production, with water absorption of $14 \%$, the $w / c$ ratio should be around 0.76 , in order to achieve the proper consistency of concrete. The application of aggregate with water absorption of about $10 \%$ allow the right consistency of concrete with w/c ratio lower than 0.6 to be achieved. The application of chalcedonite in the road construction industry, however, is not an optimal utilization of this resource. A more efficient direction of chalcedonite utilization is its application as a gravel bed filter in the processes of water and wastewater treatment (Tchórzewska 1995; Tchórzewska 2001; Kosk 2008; Michel 2011), as an additive to the production of cement clinker (Garbacik 2005) and in production of light artificial aggregates (Góralczyk et al. 2009).

\section{Characteristics of the material}

Technological process of chalcedonite treatment includes the general operations of crushing, washing and classification. The washing process is particularly significant due to the high amount of mineral dust contained in the raw material. The high ash content is very unfavorable if the aggregate is used in concrete production. The results in Table 2 (dust content) indicate that the effectiveness of the chalcedonite washing process was low. The good quality washed aggregates, in general, contain less than $0.5 \%$ of dust. However, good results of the washing process were obtained after the application of the turbo-washer device combined with downstream washing on a screen (Naziemiec 2011), where the dust content in the product did not exceed $1 \%$.

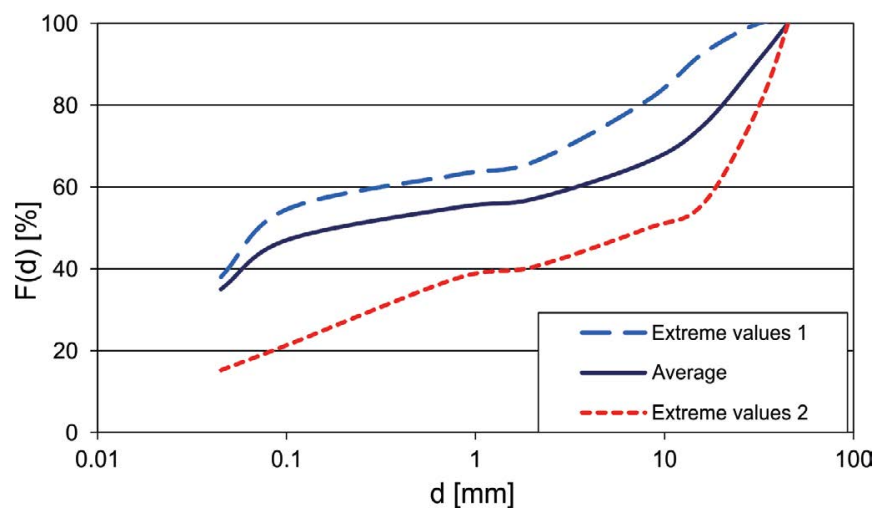

Fig. 1. Particle size composition of chalcedonite from the excavation floor, constituting the feed for the washing process in the "Inowłódz" mine

Rys. 1. Skład ziarnowy chalcedonitu ze spągu wyrobiska, stanowiącego nadawę do płukania w kopalni "Inowłódz", 
The average particle size composition of chalcedonite mined in recent years was presented in Fig. 1. The particle size composition and dust content were determined by means of wet screening in the laboratory the sieve shaker with a sieved set selected according to norm PN-EN 933-1.

In the process of granulometric classification, the $0-0.3 \mathrm{~mm}$ particle size fraction constitutes the tails and usually goes to the settling tank. However, it is possible to separate narrower particle size fractions with different chemical composition from that product, which

Table 4. Chemical composition of chalcedonite with various particle size from "Inowłódz" mine

Tabela 4. Skład chemiczny chalcedonitu o różnym uziarnieniu z kopalni „Inowłódz”

\begin{tabular}{|c|c|c|}
\hline & Chalcedonite $0-0.3 \mathrm{~mm}$ & Chalcedonite 0-0.063 mm \\
\hline Roasting loss at $1025^{\circ} \mathrm{C}$ & 0.99 & 3.51 \\
\hline $\mathrm{SiO}_{2}$ & 96.16 & 84.28 \\
\hline $\mathrm{Al}_{2} \mathrm{O}_{3}$ & 1.96 & 8.67 \\
\hline $\mathrm{Fe}_{2} \mathrm{O}_{3}$ & 0.36 & 1.12 \\
\hline $\mathrm{TiO}_{2}$ & 0.17 & 0.41 \\
\hline $\mathrm{CaO}$ & 0.05 & 0.21 \\
\hline $\mathrm{MgO}$ & 0.09 & 0.48 \\
\hline $\mathrm{K}_{2} \mathrm{O}$ & 0.25 & 1.12 \\
\hline $\mathrm{Na}_{2} \mathrm{O}$ & 0.02 & 0.23 \\
\hline
\end{tabular}

Table 5. Phase composition of chalcedonite from the settling tank and the "Inowłódz" mine

Tabela 5. Skład fazowy chalcedonitu z osadnika i kopalni „Inowłódz”

\begin{tabular}{|l|c|c|c|}
\hline & Particle size [mm] & Mineral type & Content [\%] \\
\hline $\begin{array}{l}\text { Chalcedonite from } \\
\text { settling tank 1 }\end{array}$ & $0-0.3$ & $\begin{array}{c}\text { quartz } \\
\text { kaolinite }\end{array}$ & 3.5 \\
\hline $\begin{array}{l}\text { Chalcedonite from } \\
\text { settling tank 4 }\end{array}$ & $0-0.3$ & quartz & 96.8 \\
\hline $\begin{array}{l}\text { Chalcedonite from } \\
\text { settling tank 1 }\end{array}$ & $0-0.063$ & kaolinite & 3.2 \\
\hline & & Kuartz & 75.7 \\
Chalcedonite from & & Illite & 6.8 \\
the mine & $0-0.063$ & quartz & 84.0 \\
\end{tabular}


determines its further industrial application. Therefore, an accurate separation, especially of fine size fractions, turns out to be the significant issue in chalcedonite processing, which was also confirmed by the obtained results of the investigations. There was a significant content of the finest particle size fraction in the chalcedonite material, which was directed from the mine to mechanical processing (Fig. 1). The separation products were characterized by significant differences in their mineralogical composition, depending on the particle size. The clay minerals content is higher in the finer product, while the coarser product contains a large amount of silica, as shown in Tables 4 and 5. The chemical composition of the product was determined by means of the X-ray fluorescence method (XRF), while the X-ray diffraction method (XRD), supported by the Rietveld method was applied for qualitative and quantitative determination of mineralogical composition.

\section{Results of investigations within the applied processing methods}

\subsection{Investigations over chalcedonite separation in the classifier and cyclone}

The material characteristics, presented in chapter 1 , justifies an application of accurate particle size separation. In the first stage of investigations, the separation of fine size fractions of chalcedonite in a laboratory vertical classifier was carried out. The separation operation in this type of classifier takes part in a vertically rising current of water. The adjustment of the volume of water current results in selecting the classification cut-point. The classifier feed was the overflow material from the wheel dehydrator. Figure 2 shows the effect of sep-

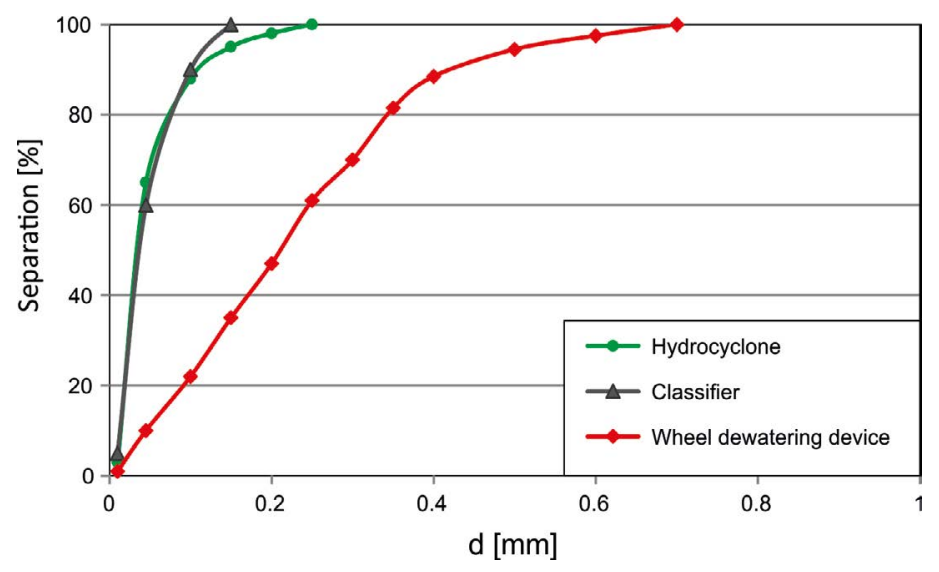

Fig. 2. Separation curves for chalcedonite slimes from hydrocyclne, vertical-current classifier and the wheel dehydrator

Rys. 2. Krzywe rozdziału szlamu chalcedonitowego dla hydrocyklonu, klasyfikatora pionowoprądowego i odwadniacza kołowego 
aration, in the form of separation curves for the solids contained in a mixture of water and mud. A relatively high efficiency of separation can be seen for that device. The cut-point for that separator was $0.044 \mathrm{~mm}$. Separation curves obtained for a hydrocyclone were also presented for comparison, as in the plant scale it may be more convenient to apply a hydrocyclone, due to larger possibilities of its regulation and process control through a suitable selection of inlet, outflow and overflow nozzles.

In the tests, carried out in the classifier, the water speed $\left(V_{O S}\right)$, was determined from the Stokes formula (Gawenda 2009):

$$
V_{O S}=546000 d^{2} \Delta[\mathrm{m} / \mathrm{s}]
$$

$\stackrel{\leftrightarrow}{\Rightarrow} d-$ size of the cut-point particle $[\mathrm{mm}]$,

$$
\begin{aligned}
& \Delta=\frac{\rho_{s}-\rho_{c}}{\rho_{c}}, \\
& \rho_{s}-\text { density of the solid, } \\
& \rho_{c}-\text { density of the liquid. }
\end{aligned}
$$

As it was mentioned the above, the separation products are characterized by a different mineralogical and chemical composition, which determines their industrial utilization. In addition to the utilization of chalcedonite fines in cement clinker production and the lightweight aggregates manufacturing, a potential utilization in ceramics can be particularly interesting. In order to assess the suitability of these fractions in typical ceramic industries,

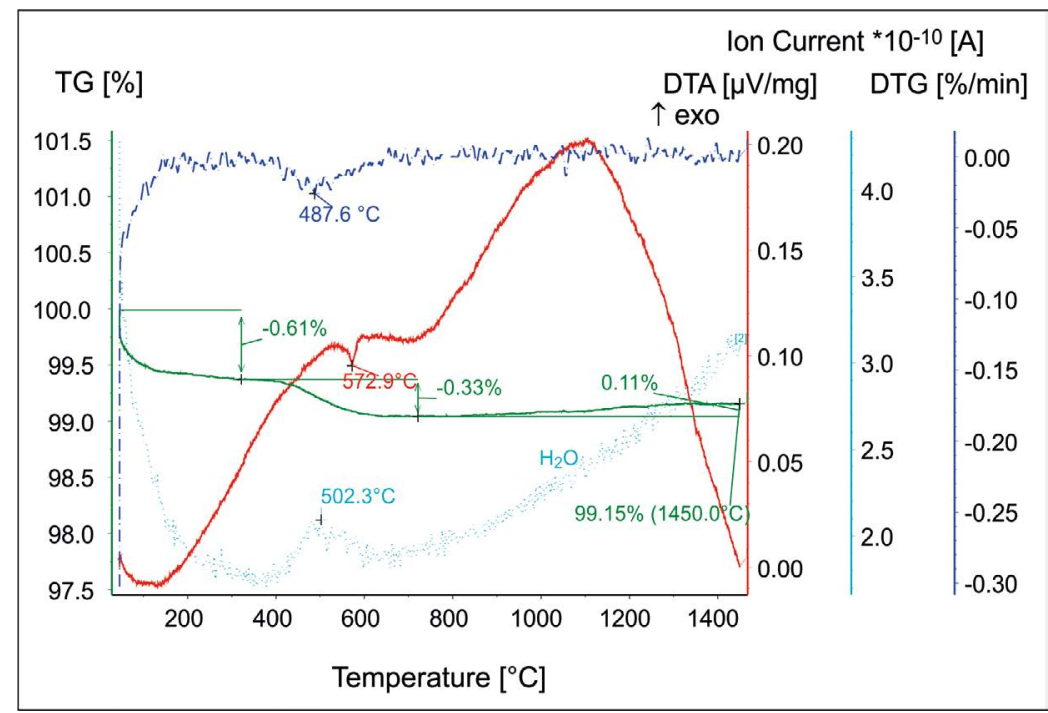

Fig. 3. Thermogram for chalcedonite sample $0 / 0.3 \mathrm{~mm}$ (slime from the washing process)

Rys. 3. Termogram próbki chalcedonitu 0/0,3 mm (szlam popłuczkowy z procesu płukania) 
a thermal analysis of chalcedonite with different particle size fractions was performed, in the temperature range from 20 to $1400^{\circ} \mathrm{C}$. The thermogram of chalcedonite sample with a $0-0.3 \mathrm{~mm}$ particle size (chalcedonite in slimes from washing process), was shown in Figure 3. There can be seen two effects caused by the separation of bound water: at $200^{\circ} \mathrm{C}$ the weight loss is $0.61 \%$, while at $502.3^{\circ} \mathrm{C}-0.33 \%$. Furthermore, the DTA curve shows the sharp endothermic effect with a minimum at $573.9^{\circ} \mathrm{C}$, corresponding to a polymorphic transformation of $\beta$-quartz into $\alpha$-quartz. Above the temperature of $800^{\circ} \mathrm{C}$, the weight of the sample increases slightly and until the temperature of $1450^{\circ} \mathrm{C}$ this increase equals $0.11 \%$. No components able to oxidize and increase their weight have been identified.

The study shows that utilization of fine particle size fractions of waste in typical ceramic industry is possible, although it does not produce a ceramic material with an extraordinary quality. Adding a chalcedonite resulted in, among others, increasing the mechanical strength, noticeable for samples fired at $1300^{\circ} \mathrm{C}$. The utilization of chalcedonite fines in coloring of ceramic articles can be more effective, due to the high efficiency of incorporation of hematite into the porous structure of chalcedonite (Naziemiec et al. 2015).

\subsection{Investigations over the density separation of chalcedonite}

All the previously conducted research on chalcedonite aggregates were based on average products of crushing, washing and screening, obtained from the raw material from different areas of exploitation. As it was mentioned the above, chalcedonite occurs in various types. In order to provide optimal utilization of this unique raw material, separation tests in the pulsating jig were carried out, in order to obtain products of different density and water absorption. Analyzing the test results, regarding the density and water absorption for chalcedonite grits and evaluating the water absorption for the concrete produced with using of chalcedonite aggregate, the purposefulness of conducting the density separation for chalcedonite should be noted. Suitable tests were performed in the laboratory pulsating jig, the feed material particle size was $4-8$ and $4-16 \mathrm{~mm}$. In order to determine the water absorption, the samples were taken from four different layers of the jig. The determination of the density and water absorption was carried out according to EN 1097-6 norm. The results are presented in Table 6 and 7, while the changes in the water absorption are shown in Figure 4. As it can be seen, the separation products have different water absorption.

Table 6 , shows the density values, obtained for the $4-8 \mathrm{~mm}$ chalcedonite in individual layers, while Table 7 presents analogous results for $8-16 \mathrm{~mm}$ material. Both tables show three different density values:

- $\rho_{a}$-the volumetric density of the aggregate particles $\left[\mathrm{Mg} / \mathrm{m}^{3}\right]-$ the ratio of the mass of dry aggregate to the volume of aggregate in water together with closed internal voids, but without voids available for water.

- $\rho_{r d}$ - the ratio of the mass of dry aggregate to the volume of aggregate in water together with closed internal voids, and with the voids available for water. 


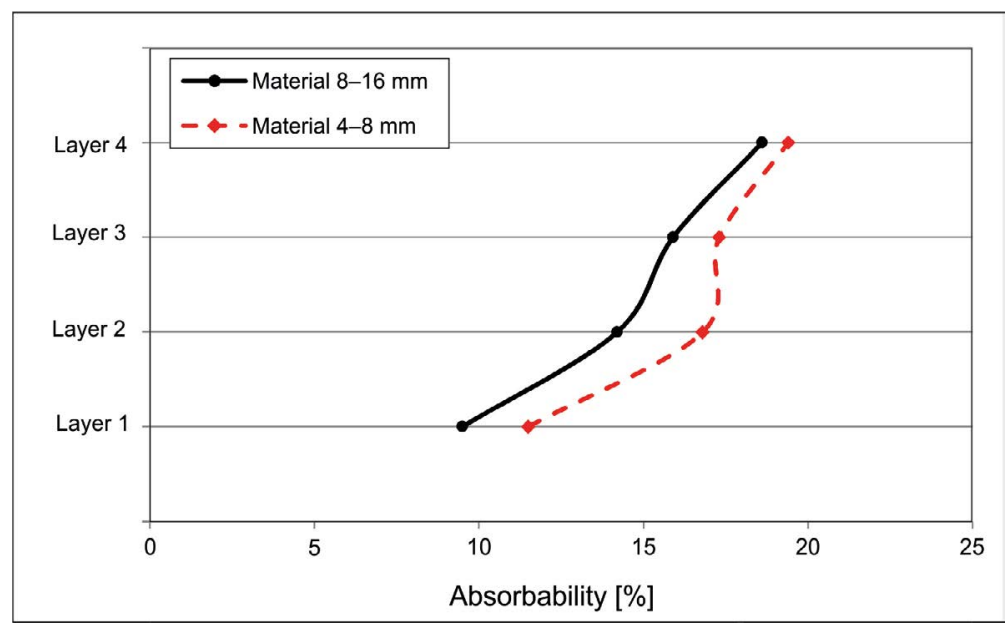

Fig. 4. Absorbability of chalcedonite separated in the pulsating jig

Rys. 4. Nasiąkliwość chalcedonitu rozdzielonego w osadzarce pulsacyjnej

Table 6. Values of $4 / 8 \mathrm{~mm}$ chalcedonite aggregate density separated in the jig

Tabela 6. Wartości gęstości kruszywa chalcedonitowego 4/8 mm rozdzielonego w osadzarce

\begin{tabular}{|l|c|c|c|c|}
\hline \multirow{2}{*}{} & \multicolumn{4}{|c|}{ Chalcedonite product } \\
\cline { 2 - 5 } & Layer 4 (upper) & Layer 3 & Layer 2 & Layer 1 (lower) \\
\hline Volumetric density $\rho_{\mathrm{a}}\left[\mathrm{Mg} / \mathrm{m}^{3}\right]$ & 2.36 & 2.37 & 2.37 & 2.42 \\
\hline Density of dry particles $\rho_{\mathrm{rd}}\left[\mathrm{Mg} / \mathrm{m}^{3}\right]$ & 1.62 & 1.68 & 1.70 & 1.89 \\
\hline Density of soaken particles $\rho_{\mathrm{ssd}}\left[\mathrm{Mg} / \mathrm{m}^{3}\right]$ & 1.93 & 1.97 & 1.98 & 2.11 \\
\hline Water absorption $\mathrm{WA}_{24}[\%]$ & 19.4 & 17.3 & 16.8 & 11.6 \\
\hline
\end{tabular}

Table 7. Values of $4 / 16 \mathrm{~mm}$ chalcedonite aggregate density separated in the jig

Tabela 7. Wartości gęstości kruszywa chalcedonitowego 4/16 mm rozdzielonego w osadzarce

\begin{tabular}{|l|c|c|c|c|}
\hline \multirow{2}{*}{} & \multicolumn{3}{|c|}{ Chalcedonite product } \\
\cline { 2 - 5 } & Layer 4 (upper) & Layer 3 & Layer 2 & Layer 1 (lower) \\
\hline Volumetric density $\rho_{\mathrm{a}}\left[\mathrm{Mg} / \mathrm{m}^{3}\right]$ & 2.28 & 2.31 & 2.33 & 2.38 \\
\hline Density of dry particles $\rho_{\mathrm{rd}}\left[\mathrm{Mg} / \mathrm{m}^{3}\right]$ & 1.60 & 1.69 & 1.75 & 1.94 \\
\hline Density of soaken particles $\rho_{\mathrm{ssd}}\left[\mathrm{Mg} / \mathrm{m}^{3}\right]$ & 1.90 & 1.96 & 2.00 & 2.13 \\
\hline Water absorption $\mathrm{WA}_{24}[\%]$ & 18.6 & 15.8 & 14.2 & 9.6 \\
\hline
\end{tabular}


- $\rho_{s s d}$ - the ratio of the mass of aggregate and the mass of water in the voids available for water to the volume of aggregate in water together with closed internal voids and empty voids available for water.

By analyzing the obtained results, it can be seen that the differences for particular densities are high for chalcedonite, while these differences are minimal for other types of solid rocks. For example, for limestone aggregates the difference between $\rho_{a}$ and $\rho_{r d}$ equals $0.08 \mathrm{Mg} / \mathrm{m}^{3}$, and for gravel aggregates the same difference is within the range of 0.05 to $0.15 \mathrm{Mg} / \mathrm{m}^{3}$.

The next stage of investigative program includes analyses performed on mercury porosimeter for both separation products. In the jig separation process on the plant scale, usually two products are obtained, therefore in the further analysis each two upper and two lower layers were combined. The results are shown in Table 8. Apart from the density, values of porosity and permeability were also presented.

Table 8. Results of porosimetric analyses for chalcedonite $4 / 16$ product obtained in the jig

Tabela 8. Wyniki analiz porozymetrycznych chalcedonitu 4/16 rozdzielonego w osadzarce

\begin{tabular}{|l|c|c|c|}
\hline & Unit & Lower product from the jig & Upper product from the jig \\
\hline Actual density of particles & $\mathrm{Mg} / \mathrm{m}^{3}$ & 2.54 & 2.50 \\
\hline Apparent density of particles & $\mathrm{Mg} / \mathrm{m}^{3}$ & 2.03 & 1.75 \\
\hline Volumetric median of pores diameter & $\mu \mathrm{m}$ & 0.42 & 1.67 \\
\hline Porosity & $\%$ & 20.01 & 29.77 \\
\hline Permeability & $\mu \mathrm{m}^{2}$ & $1.1 \cdot 10^{-3}$ & $3.1 \cdot 10^{-3}$ \\
\hline
\end{tabular}

The obtained results indicate that the application of density separation operations for chalcedonite is justified. As a result of separation process in a jig, two products can be obtained: grits for the concrete with far less water absorption and filtration grits with increased porosity and permeability. These features are important, both in the case of the utilization of chalcedonite for concrete grit, and in the grits used as filler filters for water and sewage purification. The grits with lower water absorption guarantee obtaining concrete with more favorable qualitative parameters. In the production of grit filter, in turn, an important feature is the high porosity and surface area of the grits. At present, the filter grits with a particle size of $0.8-2.5 \mathrm{~mm}$ had a specific surface area of around $5 \mathrm{~m}^{2} / \mathrm{g}$. After separation of chalcedonite in the jig, the grits with a specific surface area of $7.0 \mathrm{~m}^{2} / \mathrm{g}$ and a porosity of up to $30 \%$ were obtained. The porosity of the product at the bottom layer of the jig was $20 \%$. Obtaining the grits with higher porosity is also advantageous in the case of their utilization in gardening, because it helps to retain more water. 
Chalcedonite separation tests in the jig were also carried out for coarser particle size fractions of aggregate -8 to $31.5 \mathrm{~mm}$ - and the experimental scheme was presented in Figure 5 . After the separation process in the pulsating jig, the layer of aggregate was divided into two products: a light product with lower density and a heavy one, comprised of aggregates of higher density. Then, each product was subjected to dense medium separation (DMS). The particle size distribution of the feed and the separation products are presented in Table 9.

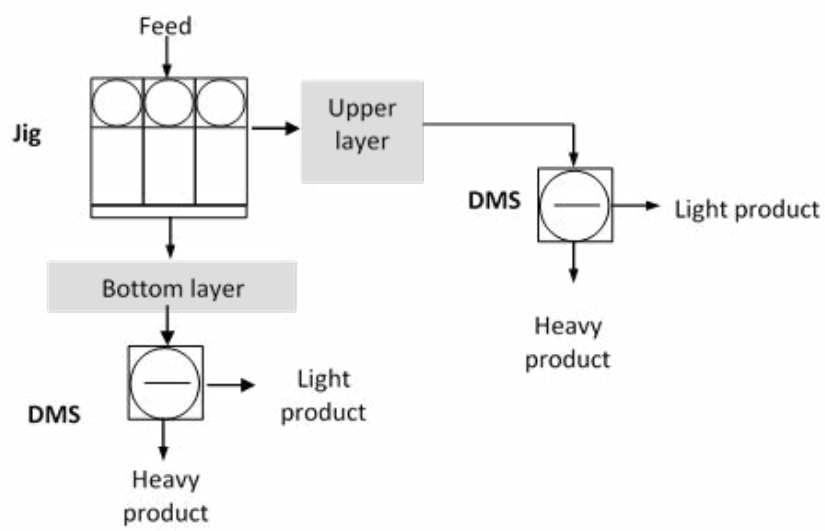

Fig. 5. Investigative scheme

Rys. 5. Schemat przeprowadzenia doświadczeń

Table 9. Particle size composition of chalcedonite feed and separation products in the jig

Tabela 9. Skład ziarnowy nadawy i produktów rozdziału chalcedonitu w osadzarce

\begin{tabular}{|c|c|c|c|}
\hline \multirow{2}{*}{ Particle size fraction $[\mathrm{mm}]$} & \multicolumn{3}{|c|}{ Percentage content [\%] } \\
\cline { 2 - 4 } & feed & upper product & lower product \\
\hline$>31.5$ & 0 & 0 & 0 \\
\hline $22.4-31.5$ & 33.8 & 28.4 & 41.7 \\
\hline $16-22.4$ & 55.4 & 58.1 & 51.6 \\
\hline $8-16$ & 10.8 & 13.5 & 6.7 \\
\hline$<8$ & 0 & 0 & 0 \\
\hline
\end{tabular}

The influence of particle size on the effects of the separation in the jig is evident. Coarse particles $(>22.4 \mathrm{~mm})$ predominate in the bottom product, but despite that particles in the bottom layer were of a higher density and lower water absorption, which indicates that the separation of aggregates with different densities took part. The results are presented in Table 10. 
Table 10. Density and water absorption of separation products in the jig

Tabela 10. Gęstość i nasiąkliwość produktów rozdziału chalcedonitu w osadzarce

\begin{tabular}{|l|c|c|c|}
\hline \multirow{2}{*}{} & \multicolumn{2}{|c|}{ Chalcedonite aggregate from the jig } \\
\cline { 2 - 4 } & $\begin{array}{c}\text { upper layer } \\
\text { (light aggregate) }\end{array}$ & $\begin{array}{c}\text { lower layer } \\
\text { (heavy aggregate) }\end{array}$ & difference \\
\hline volumetric density $\rho_{\mathrm{a}}\left[\mathrm{mg} / \mathrm{m}^{3}\right]$ & 2.32 & 2.37 & 0.05 \\
\hline Density $\rho_{r d}\left[\mathrm{mg} / \mathrm{m}^{3}\right]$ & 1.71 & 1.96 & 0.25 \\
\hline Density $\rho_{s s d}\left[\mathrm{mg} / \mathrm{m}^{3}\right]$ & 1.97 & 2.14 & 0.17 \\
\hline Water absorption wa $\mathrm{wa}_{24}[\%]$ & 15.4 & 8.7 & 6.7 \\
\hline
\end{tabular}

In order to evaluate the effectiveness of separation in a jig, an aggregate with size $8-31.5 \mathrm{~mm}$ was separated in a homogeneous dense liquid (zinc chloride), with a density of $1.98 \mathrm{Mg} / \mathrm{m}^{3}$. Table 11 shows the contents of the aggregate with a density below and above $1.98 \mathrm{Mg} / \mathrm{m}^{3}$, in the upper and bottom layer in the jig. Table 12 , in turn, shows the density and water absorption of the aggregate separated in the dense medium, using the heavy liquid with the density of $1.98 \mathrm{Mg} / \mathrm{m}^{3}$.

Table 11. Contents of particles with various densities in the individual layers in the jig

Tabela 11. Zawartość ziaren o różnej gęstości w poszczególnych warstwach w osadzarce

\begin{tabular}{|c|c|c|}
\hline & \multicolumn{2}{|c|}{ Chalcedonite aggregate from the jig [\%] } \\
\hline & $\begin{array}{l}\text { light aggregate } \\
\text { (upper layer) }\end{array}$ & $\begin{array}{c}\text { heavy aggregate } \\
\text { (lower layer) }\end{array}$ \\
\hline Content of particles with density $>1.98 \mathrm{Mg} / \mathrm{m}^{3}$ & 13.4 & 73.2 \\
\hline Content of particles with density $<1.98 \mathrm{Mg} / \mathrm{m}^{3}$ & 86.6 & 26.8 \\
\hline
\end{tabular}

If the separation process in the jig reached $100 \%$ efficiency, $0.0 \%$ should be listed instead of $13.4 \%$ in Table 11 . A similar situation applies to the value of $26.8 \%$. In other words, in the upper layer no particles with a density greater than $1.98 \mathrm{Mg} / \mathrm{m}^{3}$ should be found, while in the lower layer, only particles with a density lower than $1.98 \mathrm{Mg} / \mathrm{m}^{3}$ should be found. The results indicate that the effectiveness of the separation is not perfect $(86.6 \%$ for the upper layer and $73.2 \%$ for the lower layer), but this result can be improved, i.e. through directing a material in narrow particle size fractions to the process. The density and water absorption analyses were also performed for both separation products obtained in the dense medium (Table 12). 
Table 12. Density and water absorption of chalcedonite aggregate separated in dense media liquid $1.98 \mathrm{Mg} / \mathrm{m}^{3}$

Tabela 12. Gęstość i nasiąkliwość kruszywa chalcedonitowego rozdzielonego w cieczy ciężkiej o gęstości $1,98 \mathrm{Mg} / \mathrm{m}^{3}$

\begin{tabular}{|l|c|c|c|}
\hline \multirow{2}{*}{} & \multicolumn{2}{|c|}{ Chalcedonite aggregate } \\
\cline { 2 - 4 } & $\begin{array}{c}\text { light aggregate } \\
\text { (upper layer) }\end{array}$ & $\begin{array}{c}\text { heavy aggregate } \\
\text { (lower layer) }\end{array}$ & difference \\
\hline Volumetric density $\rho_{\mathrm{a}}\left[\mathrm{mg} / \mathrm{m}^{3}\right]$ & 2.55 & 2.57 & 0.02 \\
\hline Density $\rho_{\mathrm{rd}}\left[\mathrm{mg} / \mathrm{m}^{3}\right]$ & 1.87 & 2.20 & 0.33 \\
\hline Density $\rho_{\mathrm{ssd}}\left[\mathrm{mg} / \mathrm{m}^{3}\right]$ & 2.14 & 2.34 & 0.20 \\
\hline Water absorption wa $\mathrm{wa}_{24}[\%]$ & 14.6 & 6.30 & 8.30 \\
\hline
\end{tabular}

The aggregate separated in the dense liquid is characterized by a significant difference in water absorption and the variability of strength parameters. In abrasion resistance tests performed using the micro Deval method, the $M_{D E}=58 \%$ for the lightweight aggregate, and $M_{D E}=22 \%$ for the heavy aggregate (the lower layer).

\section{Summary and conclusions}

Chalcedonite is a unique silica rock, of multi-purpose utilization in the production of building materials and environmental protection. It is particularly suitable for the production of grit filter and as a component of sets of raw materials feed in the firing process (lightweight aggregate and cement clinker production). Intense fragmentation of fine particle size fractions of chalcedonite and its mineral composition, wherein the amorphous (microcrystalline) silica is dominated, causes lower energy consumption in the firing processes. The washing process is a primary operation in chalcedonite processing technology. Due to the high content of clay minerals and dust, washing devices with high operational efficiency are required, such as turbo washers. Chalcedonite is one of the few rocks characterized by high variability in density and water absorption, and aggregates with variable qualitative parameters (density, water absorption, surface area) are of the limited utilization in building and road construction. However, the results of investigations presented in the paper show that, to some extent, it might be possible to overcome the above problems. This is especially connected with the application of density separation in technological circuits of chalcedonite rock treatment and processing. The products of density separation operations show a lower variation in selected qualitative parameters, which creates potentials for their effective utilization, and will help in the more sustainable management of this unique raw material. 


\section{REFERENCES}

Garbacik, A. 2005. Określenie przydatności chalcedonitu „Mikrosil” jako surowca krzemonośnego do produkcji klinkieru portlandzkiego w Cementowni Rudniki. Praca IMMB Kraków (in Polish).

Gawenda, T. 2009. Klasyfikacja drobnych piasków w klasyfikatorach przepływowych hydraulicznych poziomoi pionowoprądowych. Surowce i Maszyny Budowlane no. 3 (in Polish).

Góralczyk et al. 2009 - Góralczyk, S., Mazela, A., Uzunow, E. and Naziemiec, Z. 2009. Kruszywa lekkie z osadów ściekowych i odpadów mineralnych. Prace Naukowe Instytutu Górnictwa Politechniki Wrocławskiej. Studia i Materiaty vol. 125, nr 35 (in Polish).

Kosk, I. 2008. Wpływ zróżnicowania chalcedonitów ze złoża Teofilów nad Pilica na ich walory surowcowe. Rozprawa doktorska. Uniwersytet Śląski (in Polish).

Kosk, I. 2010. Kompleksowe zagospodarowanie odpadowych surowców chalcedonitowych z osadników kopalni Inowłódz w ochronie środowiska oraz w przemyśle materiałów budowlanych. Gospodarka Surowcami Mineralnymi-Mineral Resources Management vol. 26, iss. 1 (in Polish).

Kowol, D. and Matusiak, P. 2015. Badanie skuteczności osadzarkowego oczyszczania kruszywa z ziaren węglanowych. Mining Science vol. 22, Special Issue 1.

Michel, M. 2011. Charakterystyka chalcedonitu ze złoża Teofilów pod kątem możliwości wykorzystania w technologii uzdatniania wody i oczyszczania ścieków. Gospodarka Surowcami Mineralnymi - Mineral Resources Management vol. 27, iss. 1 (in Polish).

Michel M. 2012. A study of application the modified chalcedonite for underground water treatment. Annals of Warsaw University of Life Sciences, Land Reclamation vol. 44(2).

Mróz, H. and Naziemiec, Z. 2007. Badania kruszywa chalcedonitowego pod katem przydatności do produkcji betonu oraz badania betonu sporządzonego z udziałem tego kruszywa. Opracowanie ICiMB. Kraków (in Polish).

Naziemiec et al. 2015 - Naziemiec, Z., Dziubak, C. and Stec, K. 2015. Wykorzystanie oczyszczonych drobnych frakcji chalcedonitu z Kopalni Inowłódz w przemyśle ceramiki i materiałów budowlanych. Praca statutowa ICiMB. Kraków (in Polish).

Naziemiec et al. 2017 - Naziemiec, Z., Pichniarczyk, P. and Saramak, D. 2017. Current issues of processing and industrial utilization of chalcedonite. Inżynieria Mineralna, Journal of the Polish Mineral Engineering Society no. 1(36).

Naziemiec, Z. 2011. Turbopłukanie. Surowce i Maszyny Budowlane no. 5 (in Polish).

PN-EN 1097-6:2013. Badania mechanicznych i fizycznych właściwości kruszyw. Część 6: oznaczanie gęstości ziarn i nasiąkliwości (in Polish)

PN-EN 933-1:2012. Badania geometrycznych właściwości kruszyw. Część 1: Analiza sitowa (in Polish).

Raport Końcowy 1997. Kompleksowe zagospodarowanie i racjonalne wykorzystanie surowca ze złoża „Teofilów”, ze szczególnym uwzględnieniem ochrony środowiska. Projekt celowy nr 77668 C/1969 IMMB Kraków (in Polish).

Ratajczak, T. and Wyszomirski, P. 1991. Charakterystyka mineralogiczno surowcowa chalcedonitów spongliolitowych z Teofilowa nad Pilicą. Gospodarka Surowcami Mineralnymi-Mineral Resources Management vol. 7 , iss. 1 (in Polish).

Sałaciński, R. and Puff, Z. 2003. Technologia otrzymywania syntetycznego wollastonitu z kopalin towarzyszących i odpadowych ze złóż regionu piotrkowskiego. Górnictwo Odkrywkowe no. 6, pp. 30-34 (in Polish).

Tchórzewska, D. and Pabis, J. 1997. Dodatek nr 2 do dokumentacji geologicznej złoża chalcedonitu „,Teofilów” w kat. $B+C 1+C 2$. Prace IMMB Kraków (in Polish).

Tchórzewska et al. 1995 - Tchórzewska, D., Kosk, I. and Pabis, J. 1995. Racjonalne wykorzystanie unikalnych złóż surowcowych. Cement Wapno Gips no. 2, pp. 55-57 (in Polish).

Tchórzewska et al. 2001 - Tchórzewska, D., Pabis, J., Kosk, I. and Nieć, M. 2001. Nowe zastosowania chalcedonitu jako sorbentu w procesie oczyszczania wód. Przegląd Geologiczny vol. 49 (in Polish). 


\title{
METODY POPRAWY EFEKTYWNOŚCI PRZERÓBKI CHALCEDONITU POPRZEZ ZASTOSOWANIE SEPARACJI DENSYMETRYCZNEJ
}

\author{
Słowa kluczowe \\ przeróbka chalcedonitu, separacja densymetryczna, klasyfikacja
}

\section{Streszczenie}

Artykuł dotyczy zagadnień związanych z przeróbką chalcedonitu za pomocą operacji klasyfikacji ziarnowej oraz separacji densymetrycznej. Chalcedonit jest unikalnym surowcem skalnym z szerokimi możliwościami wykorzystania przemysłowego w różnych gałęziach przemysłu. Przedstawiony w artykule program badawczy obejmuje laboratoryjne testy klasyfikacji chalcedonitu w separatorze oraz osadzarce, oraz jego separację w cieczy ciężkiej. Otrzymane wyniki pokazują, że produkty klasyfikacji ziarnowej charakteryzują się zróżnicowanym składem chemicznym i mineralogicznym. Klasa ziarnowa $0-0,3 \mathrm{~mm}$ zawierała $96 \%$ kwarcu, natomiast materiał poniżej $0,063 \mathrm{~mm}$ zawierał około $80 \%$ kwarcu i $20 \%$ minerałów ilastych.

W kolejnym etapie badań przeprowadzono separację densymetryczną chalcedonitu w osadzarce i cieczy ciężkiej. Wyniki separacji w osadzarce wskazują na zróżnicowaną nasiąkliwość otrzymanych frakcji gęstościowych chalcedonitu. Frakcje o wyższej gęstości charakteryzowały się niższą nasiąkliwością. Wyniki separacji w cieczy ciężkiej również wskazywały, że otrzymane frakcje gęstościowe kruszywa charakteryzowały się zróżnicowaną nasiąkliwością oraz zmiennością parametrów wytrzymałościowych. Uzyskane wyniki badań pokazują, że produkty klasyfikacji gęstościowej mogą być bardziej efektywnie wykorzystane w przemyśle ze względu na zróżnicowane właściwości chemiczne i fizyczne.

\section{METHODS OF IMPROVEMENT CHALCEDONITE PROCESSING EFFECTIVENESS WITH THE USE OF DENSITY SEPARATION}

\section{Keywords}

chalcedonite processing, densimetric separation, classification

\section{Abstract}

The article regards the issues related to chalcedonite processing by means of particle size classification as well as densimetric separation. Chalcedonite is an unique rock and material with wide industrial applications in various industries. The investigative program included laboratory tests of chalcedonite classification in the classifier and the jig, as well as separation of the material in the dense liquid. The obtained results indicate that the products of particle size classification of chalcedonite in the classifier are characterized by a different chemical and mineralogical composition. The $0-0.3 \mathrm{~mm}$ particle size fraction contains over $96 \%$ of quartz, while the fine size fraction below $0.063 \mathrm{~mm}$ contain about $80 \%$ of quartz and $20 \%$ of clayish minerals. 
In the next stage of the investigative program, the densimetric separation of chalcedonite material in the jig and in dense liquid, was carried out. The results of the density classification in the jig indicate the different absorbability of the obtained chalcedonite density fractions. Fractions with a higher density were characterized by lower water absorption. The results of separation in the dense media liquid also showed that the obtained aggregate products are of significant differences in absorbability as well as high variability of the strength parameters. The results of the investigations show that the obtained products of the classification can be more efficiently utilized in industry, due to their diverse chemical and physical characteristics. 